\title{
A Review of Existing Microgrid Architectures
}

\author{
Lubna Mariam, Malabika Basu, and Michael F. Conlon \\ Electrical Power Research Centre (EPRC), School of Electrical and Electronic Engineering, Dublin Institute of Technology, \\ Kevin Street, Dublin 8, Ireland \\ Correspondence should be addressed to Malabika Basu; mbasu@ieee.org
}

Received 13 December 2012; Revised 28 February 2013; Accepted 2 March 2013

Academic Editor: Keat Teong Lee

Copyright (c) 2013 Lubna Mariam et al. This is an open access article distributed under the Creative Commons Attribution License, which permits unrestricted use, distribution, and reproduction in any medium, provided the original work is properly cited.

\begin{abstract}
The future electricity network must be flexible, accessible, reliable, and economic according to the worldwide smartgrid initiative. This is also echoed by the Sustainable Energy Authority of Ireland (SEAI) and European Electricity Grid Initiative (EEGI). In order to facilitate these objectives and to reduce green house gas (GHG) emission, research on various configurations of microgrid $(\mu \mathrm{G})$ system is gaining importance, particularly with high penetration of renewable energy sources. Depending on the resource availability, geographical locations, load demand, and existing electrical transmission and distribution system, $\mu \mathrm{G}$ can be either connected to the grid or can work in an autonomous mode. Storage can also be a part of the $\mu \mathrm{G}$ architecture. This paper presents a critical literature review of various $\mu \mathrm{G}$ architectures. The benefits of grid-connected or isolated $\mu \mathrm{G}$ with storage have also been identified.
\end{abstract}

\section{Introduction}

The term microgrid $(\mu \mathrm{G})$ refers to the concept of single electrical power subsystems associated with a small number of distributed energy resources (DERs), both renewable and/or conventional sources, including photovoltaic, wind power, hydro, internal combustion engine, gas turbine, and microturbine together with a cluster of loads $[1,2]$. The application of individual distributed energy resources as microgeneration can cause problems such as local voltage rise, the potential to exceed thermal limits of certain lines and transformers, islanding and have high capital cost [3]. Microgrid can be a better solution for these problems. In a $\mu \mathrm{G}$ system, the DERs must be equipped with proper power electronic interfaces (PEIs) and control to ensure the flexibility to operate as a single aggregated system maintaining the power quality and energy output [4]. From the grid point of view, the main advantage of a $\mu \mathrm{G}$ is that it is treated as a controlled entity within the power system which can operate as a single load. From customers point of view, $\mu \mathrm{Gs}$ are beneficial because they can meet their electrical and heat requirement locally, supply uninterruptible power, improve power quality (PQ), reduce feeder loss, and provide voltage support. Furthermore $\mu \mathrm{Gs}$ can reduce environmental pollution and global warming by utilizing low-carbon technology [4].
One of the major aims of $\mu \mathrm{G}$ is to combine benefits of nonconventional/renewable low-carbon generation technologies and high efficient combined heat and power (CHP) systems. The choice of a distributed generator mainly depends on the climate and topology of the region. Sustainability of a $\mu \mathrm{G}$ system depends on the energy scenario, strategy, and policy of that country and it varies from region to region. These topics are beyond the scope of this review.

This paper critically reviews the existing and simulated $\mu \mathrm{G}$ systems demonstrated in European regions by classifying their architecture based on integration with the grid, distribution system, communication system, energy resource, and storage. A short description of the advantages and disadvantages of the widely available and feasible distributed generators (DGs) is provided. The benefits of storage and the existing storage devices have been identified. The advantages and disadvantages of different distribution systems are also presented.

\section{Basic $\mu$ G Architecture}

The basic architecture of a $\mu \mathrm{G}$ system is presented in Figure 1, which shows that a $\mu \mathrm{G}$ system generally consists of distributed generation (DG) resource, storage systems, distribution systems, and communication and control systems. 


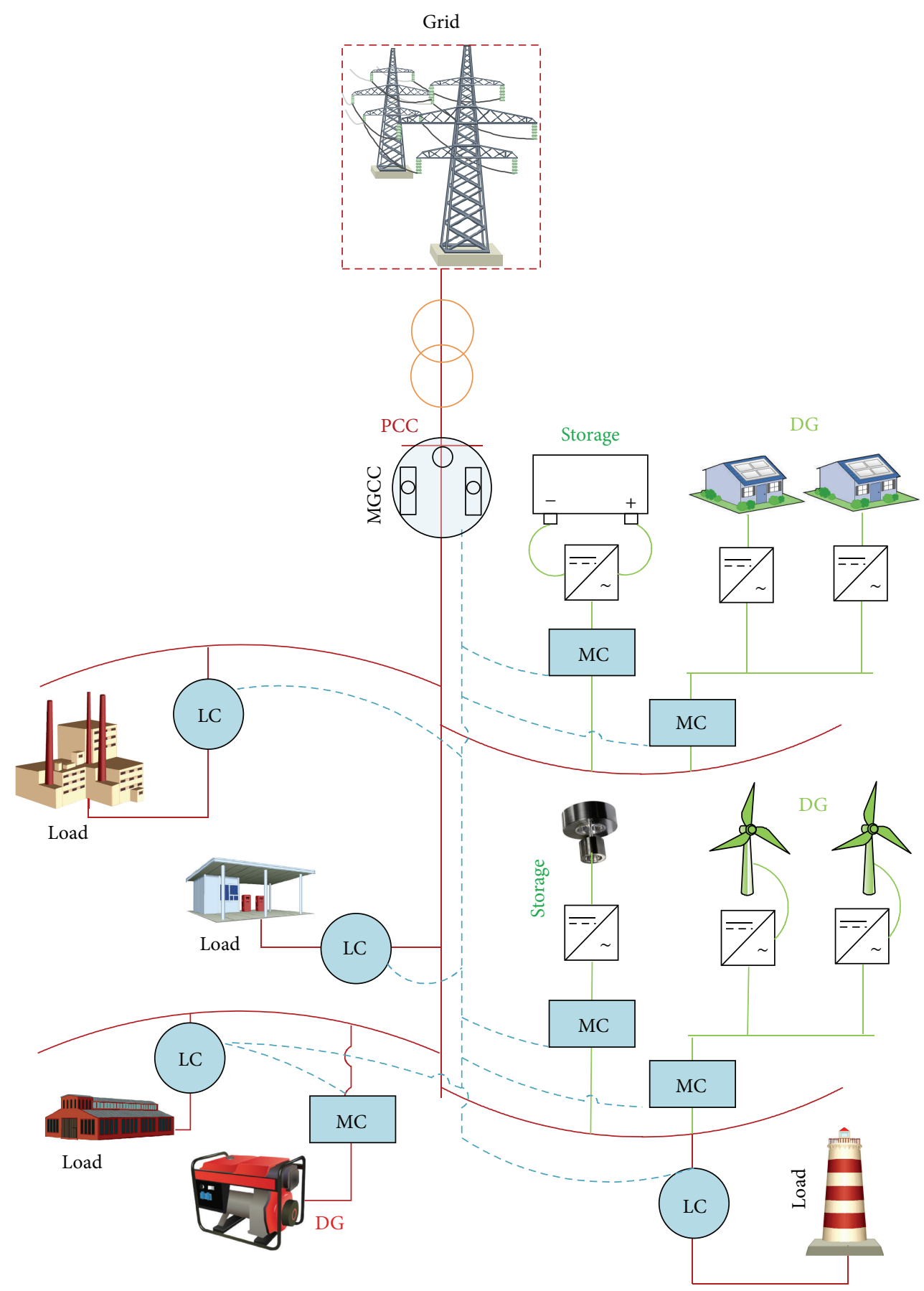

Microgrid architecture

- - Communication and control Electrical Network

MGCC Microgrid system central control
MC Microgeneration control

(LC) Local control

FIgURE 1: A simple microgrid architecture.

2.1. Distributed Generation (DG) Sources. Distributed generation technologies applicable for $\mu \mathrm{G}$ may include emerging technologies such as-wind turbine, solar PV, microhydropower, diesel, and some well-established technologies like single-phase and three-phase induction generators, synchronous generators driven by IC engines [9]. Combined heat and power (CHP) acts as a total system when heating is also used with electricity. Different kinds of sources are being used in CHP systems such as microturbines (generally driven by natural gas, hydrogen, and biogas), Stirling engines, and IC engines. CHP system allows optimum usage of energy by capturing the excess heat, thereby achieving efficiency 
TABLE 1: Typical characteristics of common DG sources $[5,6]$.

\begin{tabular}{|c|c|c|c|c|c|}
\hline Characteristics & Solar & Wind & Microhydro & Diesel & $\mathrm{CHP}$ \\
\hline Availability & $\begin{array}{l}\text { Geographical location } \\
\text { dependent }\end{array}$ & $\begin{array}{l}\text { Geographical location } \\
\text { dependent }\end{array}$ & $\begin{array}{l}\text { Geographical } \\
\text { location dependent }\end{array}$ & Any time & Dependent on source \\
\hline Output power & $\mathrm{DC}$ & $\mathrm{AC}$ & $\mathrm{AC}$ & $\mathrm{AC}$ & $\mathrm{AC}$ \\
\hline GHG emission & None & None & None & High & Dependent on source \\
\hline Control & Uncontrollable & Uncontrollable & Uncontrollable & Controllable & Dependent on source \\
\hline $\begin{array}{l}\text { Typical } \\
\text { interface }\end{array}$ & $\begin{array}{l}\text { Power electronic converter } \\
\text { (DC-DC-AC) }\end{array}$ & $\begin{array}{l}\text { Power electronic converter } \\
\text { (AC-DC-AC) }\end{array}$ & $\begin{array}{l}\text { Synchronous or } \\
\text { induction generator }\end{array}$ & None & $\begin{array}{l}\text { Synchronous } \\
\text { generator }\end{array}$ \\
\hline $\begin{array}{l}\text { Power flow } \\
\text { control }\end{array}$ & $\begin{array}{l}\text { MPPT \& DC link voltage } \\
\text { controls }(+\mathrm{P}, \pm \mathrm{Q})\end{array}$ & $\begin{array}{l}\text { MPPT, pitch \& torque } \\
\text { control }(+\mathrm{P}, \pm \mathrm{Q})\end{array}$ & $\begin{array}{l}\text { Controllable } \\
(+\mathrm{P}, \pm \mathrm{Q})\end{array}$ & $\begin{array}{l}\text { Controllable } \\
(+\mathrm{P}, \pm \mathrm{Q})\end{array}$ & $\begin{array}{l}\text { AVR and governor } \\
\quad(+\mathrm{P}, \pm \mathrm{Q})\end{array}$ \\
\hline
\end{tabular}

values of more than $80 \%$, compared to that of about $35 \%$ for conventional power plants [14]. Table 1 shows some typical characteristics of commonly used DG sources.

2.1.1. Photovoltaic $(P V)$ System. Solar PV generation involves the generation of electricity from solar energy. Due to enormous improvement in inverter technologies, PV generation is now preferred worldwide as Distributed Energy Resources (DERs). The major advantages of a PV system are

(i) the sustainable nature of solar energy,

(ii) positive environmental impact,

(iii) longer life time and silent operation.

Although photovoltaic (PV) cells can be effectively used as DERs in $\mu \mathrm{G}$ systems, they have some disadvantages including

(i) high installation cost,

(ii) low energy efficiency,

(iii) restriction to certain locations and weather dependence.

It has been reported that small PV installations are more cost effective than the larger ones [4]. As the nature of PV generation is DC power, a suitable type of power converter must be employed to convert the DC voltage to AC voltage. Some applications of PV system are [15]

(i) space programs,

(ii) remote locations where grid electricity is difficult to get,

(iii) lighting road signs and road light,

(iv) roof projects for home lighting and heating.

2.1.2. Wind Turbines (WT). Wind turbine converts wind energy into electrical energy using the wind energy conversion systems (WECSs). Wind energy has been popular for decades. Usually induction generators are used in WECSs. The main part of the wind turbine is the tower, the rotor, and the nacelle. The nacelle accommodates the mechanical transmission and the generator. Wind turbine captures the kinetic energy of wind flow through rotor blades and transfers the energy to the induction generator through the gearbox. The generator shaft is driven by the wind turbine to generate electric power. Wind turbines may have horizontal axis or vertical axis configuration. The average commercial turbine size was $300 \mathrm{~kW}$ until the mid 1990s, but recently machines of larger capacity, up to $5 \mathrm{MW}$ and more, have been developed and installed [16].

2.1.3. Micro-Hydropower System. Micro-hydropower system uses the energy of flowing water to produce mechanical or electrical energy. This energy generation system depends on the topography and annual precipitation of the area. The system suffers from large variation of water flow due to uneven rainfall and results in a variation in generation [17]. Runof-river system is often used in micro-hydropower systems which do not require large storage reservoir. A portion of the river water is diverted to a water-conveyance channel to rotate a turbine or a water wheel that spins a shaft. The motion of the shaft can be used for mechanical power such as pumping water or can be used to power a generator to generate electricity.

2.2. Storage Systems. One of the main criteria of successful operation of $\mu \mathrm{G}$ is the inclusion of energy storage devices, which balances the short-term power and energy demand with generation. Generally the $\mu \mathrm{G}$ power systems have storage through the generator inertia. When a new load comes online, it can result in a slight change in system frequency depending on its size [18]. Lasseter in [2] concluded that a system with several micro sources designed to operate in an island mode must provide some storage option to ensure energy balance. In case of some micro sources (such as fuel cells and microturbines), with large time constants in the range of 10 to 200 s, storage devices are very important to balance the power following system disturbance and/or significant load changes [18]. In the case of sudden system changes, these devices can act as an AC voltage source. Because of their physical limitations, they have limited energy storage capacity. The backup energy storage devices should be included in $\mu \mathrm{G}$ systems to ensure uninterrupted power supply. Suitable storage devices for $\mu \mathrm{G}$ system include batteries, flywheels and supercapacitors [19]. According to a report by Zpryme in [20], battery-energy storage technology will be in highest demand over the next 5 years. Table 2 summarizes some basic 

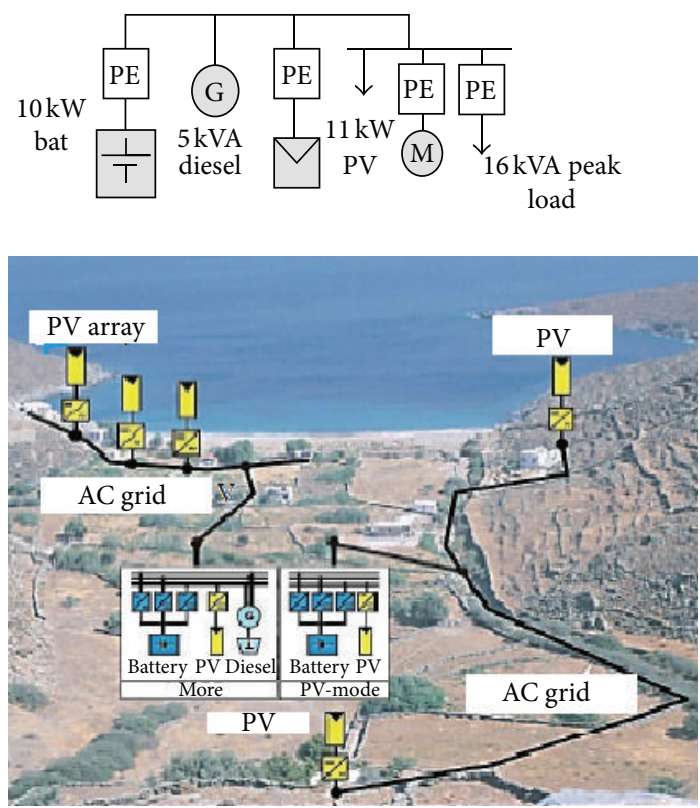

FIGURE 2: $\mu \mathrm{G}$ system with PV, diesel, and storage [7].

features about these three storage devices. The table shows that the three storage devices show the same efficiency around 90 to $95 \%$. Whereas in terms of current price, battery is less expensive than the other two. Besides that battery has high negative environmental impact whereas the other two have lesser impact on the environment. Life time of flywheel and supercapacitor is more than 10 years but battery has 5 years at best and it needs servicing each year.

Another storage option can be fuel cell that converts chemical energy of a fuel directly into electrical energy. They can be described as batteries which never discharge as long as hydrogen and oxygen are continuously provided. The output of the generator is $1 \mathrm{~kW}-10 \mathrm{MW}$. Electrical efficiency is $30-$ $60 \%$ and overall efficiency is $80-85 \%$. Moreover, they can use a variety of fuels such as natural gas, propane, landfill gas, anaerobic digester gas, diesel, naphtha, methanol, and hydrogen $[21,22]$.

Figures 2 and 3 present two $\mu \mathrm{G}$ configurations with and without storage system. Figure 2 presents Kythnos $\mu \mathrm{G}$ which is located in a remote island in Greece. In this $\mu \mathrm{G}$, solar PV system and diesel are used as DG sources and battery as storage system. This $\mu \mathrm{G}$ is isolated and electrifies 12 houses in the island. Figure 3 presents Ramea integrated wind-diesel project in Canada. Wind energy and diesel have been used as DG sources in this $\mu \mathrm{G}$. The important feature of this $\mu \mathrm{G}$ is that it is grid connected and it does not have any storage system.

2.3. Distribution Systems. The distribution network can be classified as three types:

(i) DC line,

(ii) $60 / 50 \mathrm{~Hz}$ AC line (line frequency),

(iii) high-frequency AC (HFAC).
TABLE 2: Basic features of suitable storage devices in $\mu \mathrm{G}$ system [7].

\begin{tabular}{|c|c|c|c|}
\hline Basic features & Battery & Flywheel & Supercapacitor \\
\hline $\begin{array}{l}\text { Continuous power } \\
(\mathrm{W} / \mathrm{kg})\end{array}$ & $50-100$ & $200-500$ & 500-2000 \\
\hline Typical backup time & $5-30 \mathrm{~min}$ & $10-30 \mathrm{sec}$ & $10-30 \mathrm{sec}$ \\
\hline Losses at standby & Very low & Variable & High \\
\hline $\begin{array}{l}\text { Environmental } \\
\text { impact }\end{array}$ & Medium-high & Low & Low \\
\hline Maintenance & $1 /$ year & $1 / 5$ years & None \\
\hline $\begin{array}{l}\text { Charging efficiency } \\
\text { (\%) }\end{array}$ & $75-95$ & 90 & $85-95$ \\
\hline $\begin{array}{l}\text { Current energy price } \\
(\$ / \mathrm{kWh})\end{array}$ & $150-800$ & $3000-4000$ & $4000-5000$ \\
\hline Service life (year) & 5 & 20 & $>10$ \\
\hline
\end{tabular}

2.3.1. DC Line. As most of the DERs generate DC power and the DC distribution system has no power quality problems, research on DC $\mu \mathrm{G}$ system is getting importance. But most of the loads are operated in AC system; hence, DC distribution system may not be popular yet. Figure 4 shows a DC $\mu \mathrm{G}$ system.

2.3.2. AC Line (Line Frequency). $\mu \mathrm{Gs}$ are generally line frequency $\mu \mathrm{Gs}$. The DERs are connected in a common bus in the $\mu \mathrm{G}$. The DC current from DERs is transformed to $50 \mathrm{~Hz}$ AC by a suitable inverter and then transmitted to the load side. Figure 5 shows an $\mathrm{AC} \mu \mathrm{G}$ system.

2.3.3. High Frequency AC (HFAC). There are many ways to connect distributed energy sources in $\mu \mathrm{G}$ system. Using HFAC to transmit electricity in $\mu \mathrm{G}$ is a new concept which is still at the developmental stage. In HFAC $\mu \mathrm{G}$, the DERs are connected to a common bus. The electricity generated by the DERs is transformed to $500 \mathrm{~Hz} \mathrm{AC}$ by power electronics devices and is transmitted to the load side; it is again converted to $50 \mathrm{~Hz}$ AC by an $\mathrm{AC} / \mathrm{AC}$ converter.

The load is connected to the distribution network, which can guarantee an effective interaction between $\mu \mathrm{G}$ and distribution network. At higher frequency the harmonics of higher order are filtered thus limiting PQ problems. But disadvantage is that HFAC improves line reactance and increases power loss [23]. Figure 6 shows a HFAC $\mu \mathrm{G}$ system.

\subsection{Power Quality Issue Related to Distribution Systems.}

Power quality in $\mu \mathrm{G}$ system has become an important issue as the penetration of DG systems either connected to the grid or $\mu \mathrm{G}$ increases. Solar, wind, micro-hydro, and diesel are the most leading sources of DG systems and therefore power quality problems related to these DG systems have been identified in $[8,24]$ and shown in Table 3 . The table shows that most commonly used renewable energy sources (RESs) such as solar PV and wind energy systems can have almost all the PQ problems such as voltage sag/swell, over/under voltage, voltage and current harmonics, and flicker. Because of the varying nature of wind and sun, the abrupt changes in wind condition (velocity, direction, turbulence, etc.), and 


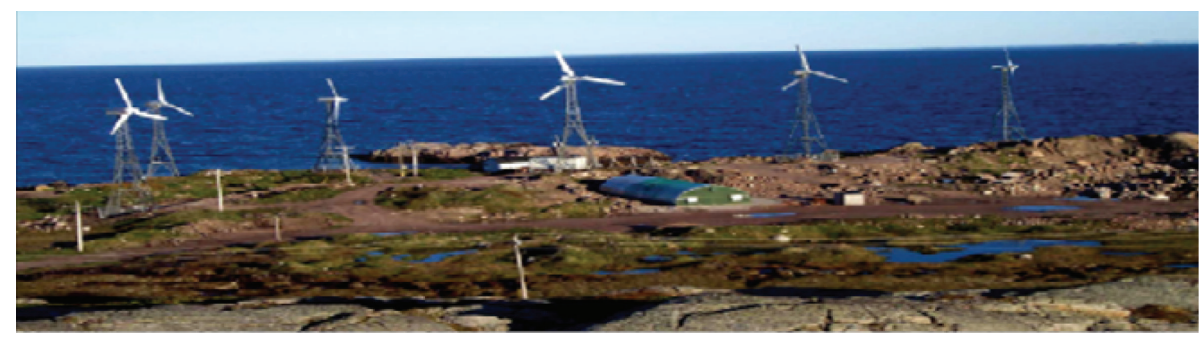

Ramea wind-diesel project

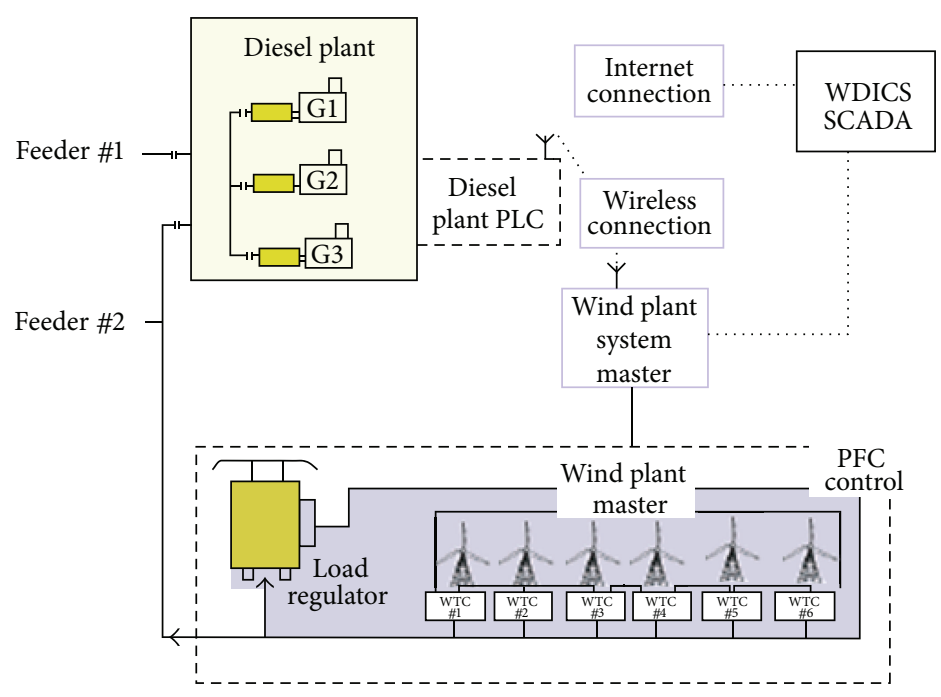

Figure 3: Microgrid system with wind and diesel (without storage) [7].

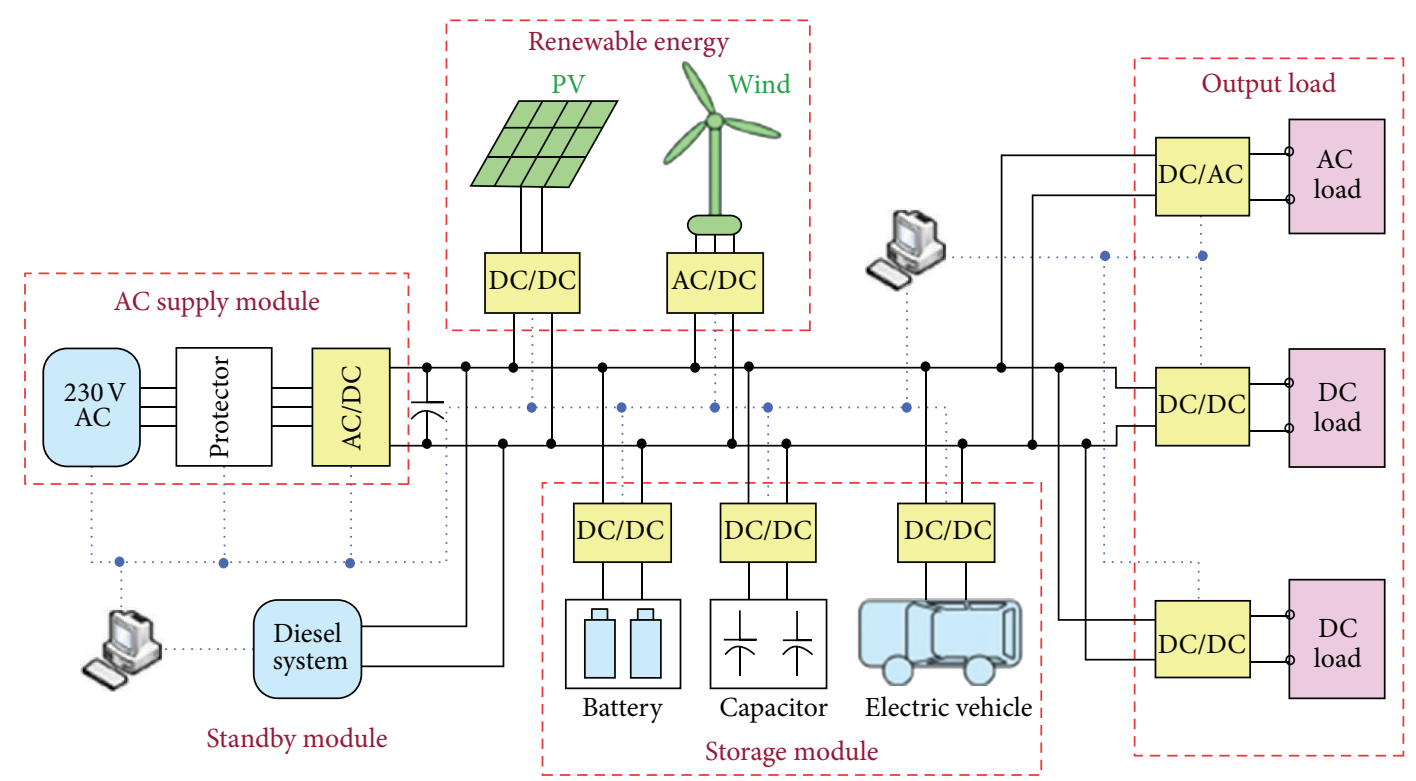

FIGURE 4: DC microgrid system [7]. 


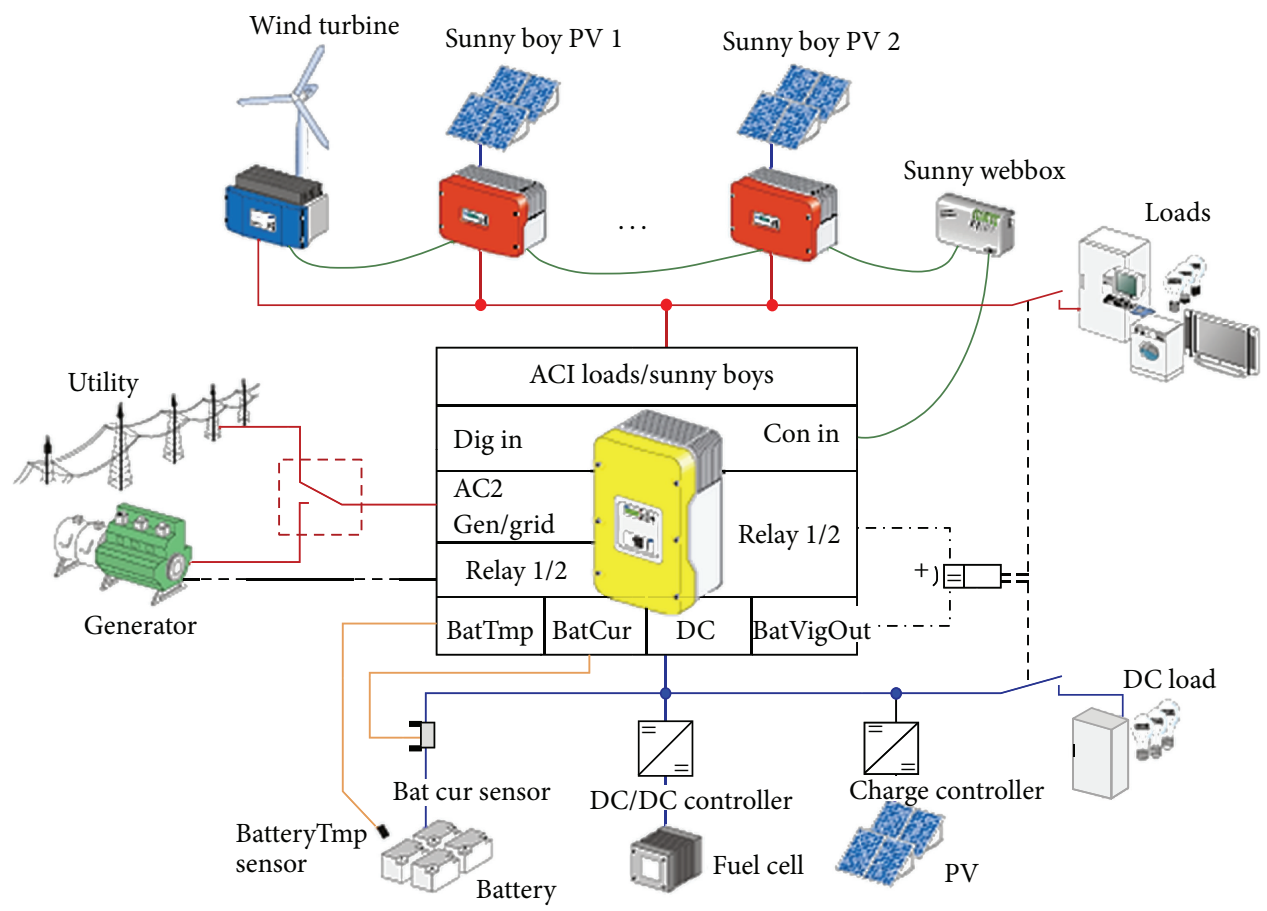

Figure 5: AC microgrid system [7].

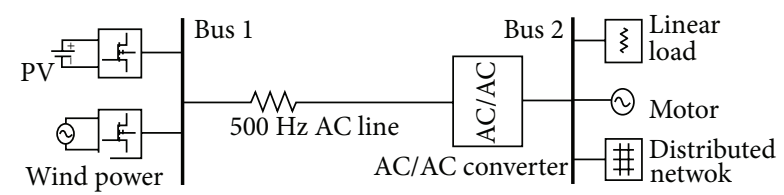

FIGURE 6: HFAC microgrid schematic chart [23].

solar radiation (due to cloud cover), the electrical output voltage can have a direct impact if not conditioned through the integration devices properly and thus causes PQ problem. Comparing to this, small/micro-hydro has lesser PQ problems. Main advantage of these RESs is they are pollution free. Conventional source diesel also has lesser power quality problems such as voltage, sag/swell, over/under voltage and flicker. Main disadvantage of this source is that it emits $\mathrm{CO}_{2}$ which pollutes the environment. So more research emphasis should be given to improve PQ problems in integrating RE sources.

2.5. Communication Systems. For power control and protection, communication systems are very important. The basic communication methods so far used in the existing $\mu \mathrm{G}$ testbeds are: power-line carrier, broadband over power line, leased telephone line, global system for mobile (GSM) communication, LAN/WAN/Internet (TCP/IP), wireless radio communication, optic fiber, WiFi 802.11b (range of a few 100 meters; speed 5-10 Mbps), WiMAX 802.16 (range 10-30 miles; speed $75 \mathrm{Mbps}$ ), and ZigBee/IEEE 802.15.4 (for automated metering system) [9].
TABLE 3: PQ problems related to DG systems [8].

\begin{tabular}{lcccc}
\hline PQ problems & $\begin{array}{c}\text { Wind } \\
\text { energy }\end{array}$ & $\begin{array}{c}\text { Solar } \\
\text { energy }\end{array}$ & $\begin{array}{c}\text { Micro/ } \\
\text { small } \\
\text { hydro }\end{array}$ & Diesel \\
\hline Voltage sag/swell & $\bullet$ & & $\bullet$ & $\bullet$ \\
Over/under voltage & $\bullet$ & & & $\bullet$ \\
Voltage unbalance & & $\bullet$ & & \\
Voltage transient & $\bullet$ & & & \\
Voltage harmonics & $\bullet$ & $\bullet$ & & \\
Flicker & $\bullet$ & $\bullet$ & & \\
Current harmonics & $\bullet$ & $\bullet$ & & \\
Interruption & $\bullet$ & $\bullet$ & & \\
\hline
\end{tabular}

\section{Existing $\mu$ G Examples in Europe}

This paper reviews different architectural structures of existing and simulated $\mu \mathrm{G}$ systems. Some of the existing $\mu \mathrm{G}$ systems in Europe are shown in Table 4. From the table it can be seen that the majority of existing testbeds in this region are AC $\mu \mathrm{Gs}$. Only one DC $\mu \mathrm{G}$ is present which is located in Italy. Table 4 shows that the majority of $\mu \mathrm{G}$ testbeds have implemented central controller system, and few of them have autonomous and agent-based system. Review showed that few testbeds have highlighted about power quality problem and implemented PQ devices to solve them. It was also found that different $\mu \mathrm{G}$ testbeds have implemented different communication systems such as LAN/WAN/Internet (TCP/IP), wireless radio communication, optic fiber, and WiFi. 
TABLE 4: Existing examples of $\mu \mathrm{Gs}$ in Europe.

\begin{tabular}{|c|c|c|c|c|c|c|c|}
\hline Location & $\begin{array}{l}\text { Power } \\
\text { supply }\end{array}$ & $\begin{array}{c}\text { DG } \\
\text { source }\end{array}$ & $\begin{array}{l}\text { Energy } \\
\text { storage }\end{array}$ & $\begin{array}{c}\mu \mathrm{G} \\
\text { controller }\end{array}$ & $\begin{array}{c}\text { PQ } \\
\text { control }\end{array}$ & Communication & Reference \\
\hline Bronsberg, The Netherlands & $\mathrm{AC}$ & PV & Battery & Central & None & GSM communication & [9] \\
\hline Am Steinweg, Germany & $\mathrm{AC}$ & $\begin{array}{l}\text { CHP, } \\
\text { PV }\end{array}$ & Battery & $\begin{array}{l}\text { Agent } \\
\text { based }\end{array}$ & ${ }^{*}$ PoMS & TCP/IP & {$[10]$} \\
\hline CESI RICERCA DER, Italy & DC & $\begin{array}{c}\text { PV, wind, diesel, } \\
\text { CHP }\end{array}$ & Battery & Central & Flywheel & $\begin{array}{l}\text { Combination of LAN } \\
\text { ethernet, wireless, and } \\
\text { power line }\end{array}$ & {$[11]$} \\
\hline Bornholm, Denmark & $\mathrm{AC}$ & $\begin{array}{l}\text { Diesel, } \\
\text { wind }\end{array}$ & None & Autonomous & None & Optical fiber network & {$[12]$} \\
\hline Kythnos, Greece & $\mathrm{AC}$ & $\begin{array}{l}\mathrm{PV} \\
\text { diesel }\end{array}$ & Battery & Central & None & Power line & {$[9]$} \\
\hline CAT, Wales, UK & $\mathrm{AC}$ & $\begin{array}{l}\text { Hydro, } \\
\text { wind, } \\
\text { PV }\end{array}$ & Battery & Central & None & Not discussed & {$[13]$} \\
\hline
\end{tabular}

* PoMS: power flow and power quality management system.

\section{Findings of the Study}

From the review of $\mu \mathrm{G}$ architectures it was found that most of the testbeds are AC $\mu \mathrm{Gs}$. As the grid and most loads are $\mathrm{AC}$, the $\mathrm{AC} \mu \mathrm{G}$ is easy to integrate with the grid. Maintaining the power quality is one of the critical tasks in AC systems. On the other hand, the main advantage in DC system is that there are few power quality problems and therefore less additional control or components are required. The application of DC $\mu \mathrm{G}$ is very limited though due to unavailability of enough DC loads. HFAC $\mu \mathrm{G}$ is a very new concept and is a possible way for integrating renewable energy sources to the $\mu \mathrm{G}$. One of the main advantages is that PQ problems are lesser in this system. The main problems of the HFAC $\mu \mathrm{G}$ system is the complexity of the control devices, large voltage drop, and higher long distance power loss, which currently limits its practical implementation but could be researched upon.

The most commonly used DG sources in $\mu \mathrm{G}$ systems are solar PV, wind, micro-hydro and diesel. RES are quite popular as DG sources in European regions along with conventional sources.

Power quality is a potential issue in $\mu \mathrm{G}$ system. As the renewable DG sources are highly dependable on environment, variability of the resource introduces some PQ problems. Hence consideration of PQ performance for any $\mu \mathrm{G}$ system is essential. Review of the test-beds shows that few $\mu \mathrm{G}$ test-beds have implemented power quality devices. Therefore, further research is required to improve their PQ and reliability and thus increase the performance of $\mu \mathrm{G}$ systems.

Storage system is one of the important options that a $\mu \mathrm{G}$ should have for its successful and stable operation. Most of the existing test-beds have battery storage; some have capacitor banks and flywheels as storage devices. Some of the $\mu \mathrm{Gs}$ have a combination of two or three storage units together and some do not have any storage units at all. From the review it was found that in most cases (except two), if there is no storage device, at least one controllable DG source is present at the system. If the system does not have any storage devices and only RES is present as DG source, then grid integration is a very important option for that $\mu \mathrm{G}$ system. Further study can be done on that regard.

\section{Conclusion}

DC $\mu \mathrm{G}$ is not very popular in European regions though it has advantages regarding lesser PQ problems; more emphasis should be given to this system. The main barrier to expand this technology is lesser amount of DC loads. As technology has been advancing, more DC-compatible loads can be introduced to overcome this situation. Most of the existing AC $\mu$ Gtest beds have included batteries as storage devices though it is expensive; further technological improvement can help the system to become economically viable.

More penetration of RESs is expected in $\mu \mathrm{G}$ systems as they are almost pollution-free and thus environment friendly. In that case potential effort should be given to solve PQ problems associated to the RE sources.

Combination of different RE systems along with storage has a potential future because it helps to store the clean energy whenever available. The advancement in storage and battery systems looks promising in terms of cost and technology. Though initial system cost and operation and maintenance cost (O\&M) may be higher, considering the requirements of demand-side management and maximizing the use of available RESs, $\mu \mathrm{G}$ with storage devices could be a viable option in the near future.

\section{References}

[1] R. H. Lasseter and P. Paigi, "Microgrid: a conceptual solution," in Proceedings of the IEEE 35th Annual Power Electronics Specialists Conference (PESC 04), pp. 4285-4290, June 2004.

[2] R. H. Lasseter, "Microgrids," in Proceedings of the IEEE Power Engineering Society Winter Meeting, vol. 1, pp. 305-308, 2002.

[3] D. Infield and F. Li, "Integrating micro-generation into distribution systems-a review of recent research," in Proceedings of the IEEE Power and Energy Society General Meeting (PES '08), pp. 1-4, July 2008. 
[4] S. Chowdhury, S. P. Chowdhury, and P. Crossley, Microgrids and Active Distribution, Networks, London, UK, 2009.

[5] F. Katiraei, R. Iravani, N. Hatziargyriou, and A. Dimeas, "Microgrids management," IEEE Power and Energy Magazine, vol. 6, no. 3, pp. 54-65, 2008.

[6] DTI, "Micro-generation strategy and low carbon buildings programme-consultation," 2005, http://www.dti.gov.uk/files/ file13989.pdf.

[7] R. Teodorescu, "Industrial PhD course on Microgrids "Microgrid Overview'", Alborg University, http://www.et.aau.dk/.

[8] S. K. Khadem, M. Basu, and M. Conlon, "UPQC for power quality improvement in DG integrated smart grid network-a review," International Journal of Emerging Electric Power Systems, vol. 13, no. 1, 2012.

[9] N. W. A. Lidula and A. D. Rajapakse, "Microgrids research: a review of experimental microgrids and test systems," Renewable and Sustainable Energy Reviews, vol. 15, no. 1, pp. 186-202, 2011.

[10] C. Bossi, T. Degner, and S. Tselepis, "Distributed generation with high penetration of renewable energy sources," Dispower, Final Public Report, Laboratory Tests Case Studies and Field Experience, Kessel, Germany, 2006.

[11] Cesi Ricerca DER Test Facility (DER-TF), Italy, http://www .microgrids.eu/.

[12] J. Ostergaard and J. E. Neilsen, The Bornholm Power System an Overview, Kgs, Lyngby, Denmark, 2011.

[13] The UK's first Island Microgrid Goes Online, CAT, Wales, UK, 2009, http://www.cat.org.uk/.

[14] S. Karki, M. Kulkarni, D. Michael, Mann, and S. Hossein, "Efficiency improvement through combined heat and power for on-site distributed generation technologies," Cogeneration and Distributed Generation Journal, vol. 22, no. 3, pp. 19-34, 2007.

[15] W. El-Khattam and M. M. A. Salama, "Distributed generation technologies, definitions and benefits," Electric Power Systems Research, vol. 71, no. 2, pp. 119-128, 2004.

[16] D. Seifried and W. Witzel, Renewable Energy the Facts, Earthscan Publisher, London, UK, 1st edition, 2010.

[17] P. Kruger, Alternative Energy Resources the Quest for Sustainable Energy, John Wiley \& Sons, 1st edition.

[18] H. Jiayi, J. Chuanwen, and X. Rong, "A review on distributed energy resources and MicroGrid," Renewable and Sustainable Energy Reviews, vol. 12, no. 9, pp. 2465-2476, 2008.

[19] B. Kroposki, R. Lasseter, T. Ise, S. Morozumi, S. Papathanassiou, and N. Hatziargyriou, "A look at microgrid technologies and testing projects from around the world, making microgrids work," IEEE Power and Energy Magazine, vol. 6, no. 3, pp. 40-53, 2008.

[20] Power systems for the future: the case for energy storage, distributed generation, and Microgrids, Sponsored by IEEE Smart Grid, with analysis by Zpryme.

[21] J. Padulles, G. W. Ault, and J. R. McDonald, "An approach to dynamic modeling of fuel cell characteristics for distributed generation operation," in Proceedings of the IEEE/PES Winter Meeting, vol. 1, pp. 134-138, 2000.

[22] S. A. Shakur, Investigating the dynamic performance of renewable electric generation systems [M.S. thesis], Thapar University, Patiala, India, 2011.

[23] X. Li, A. Xin, and Y. Wang, "Study of singe phase HFAC Microgrid based on MATLAB/Simulink," in Proceedings of the IEEE Conference on Electric Utility Deregulation Restructuring and Power Technologies (DRPT '11), pp. 1104-1108, 2011.
[24] S. K. Khadem, M. Basu, and M. Conlon, "Power quality in grid connected renewable energy systems: role of custom power devices," in Proceedings of the ICREPQ, 2010. 

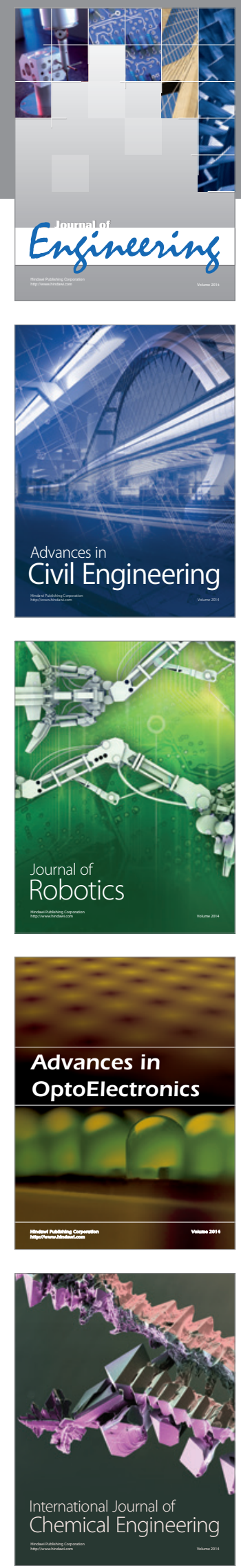

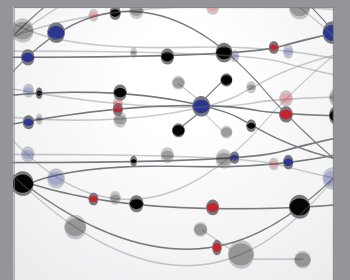

The Scientific World Journal
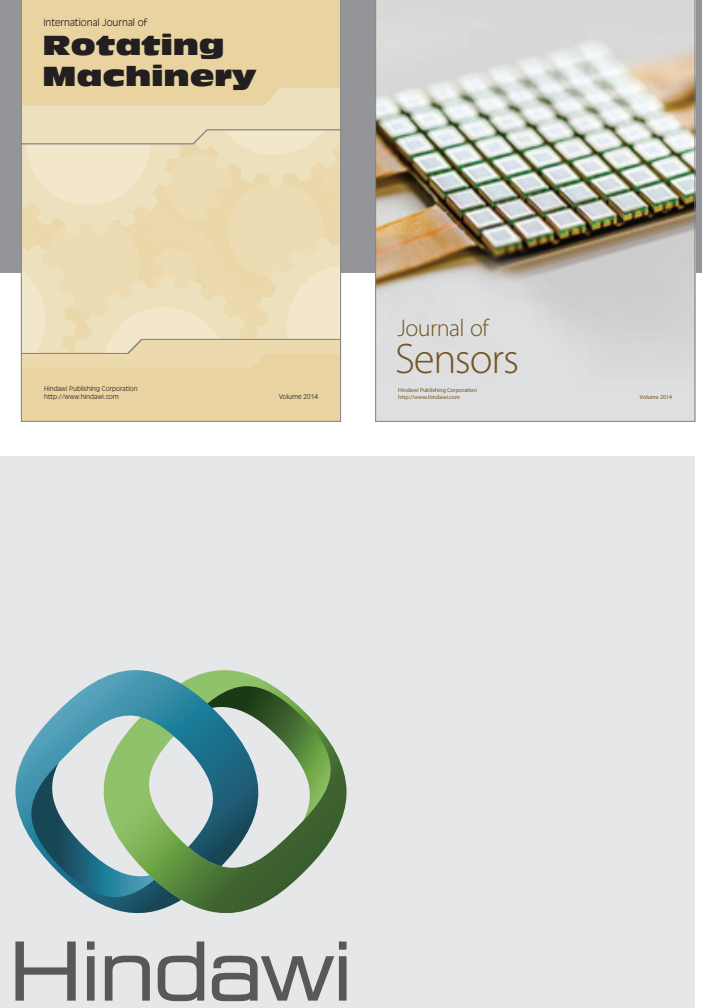

Submit your manuscripts at http://www.hindawi.com
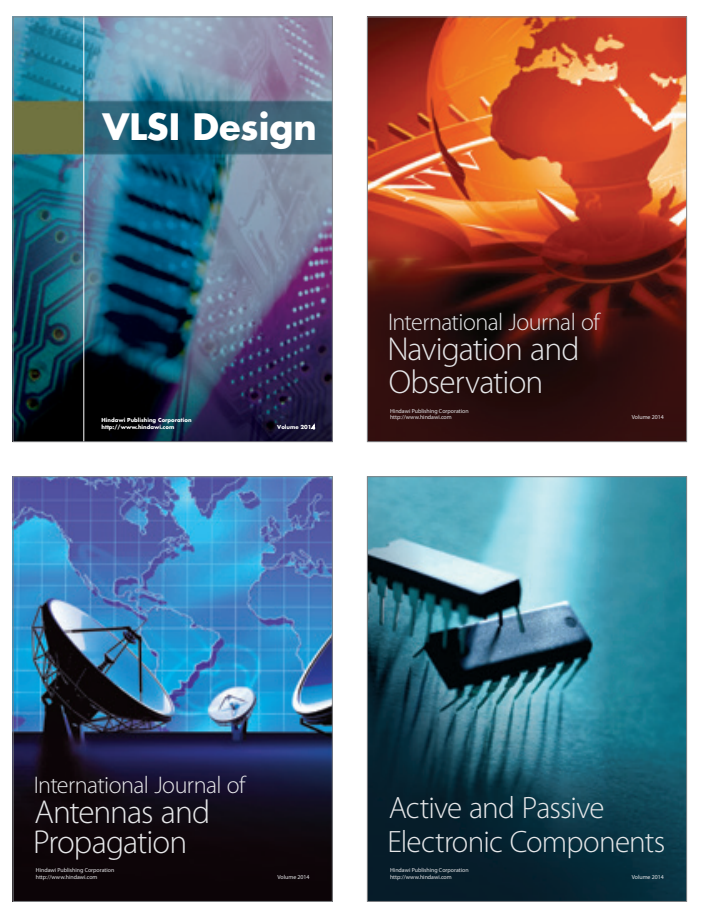
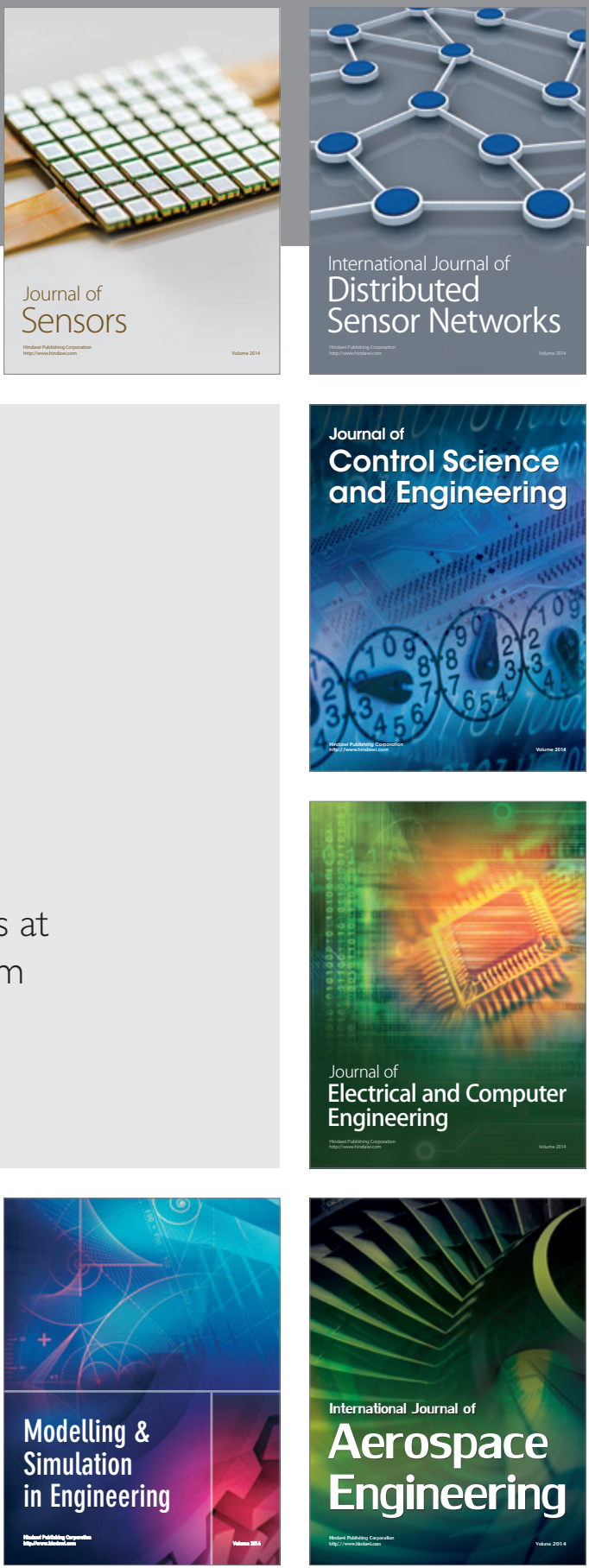

Journal of

Control Science

and Engineering
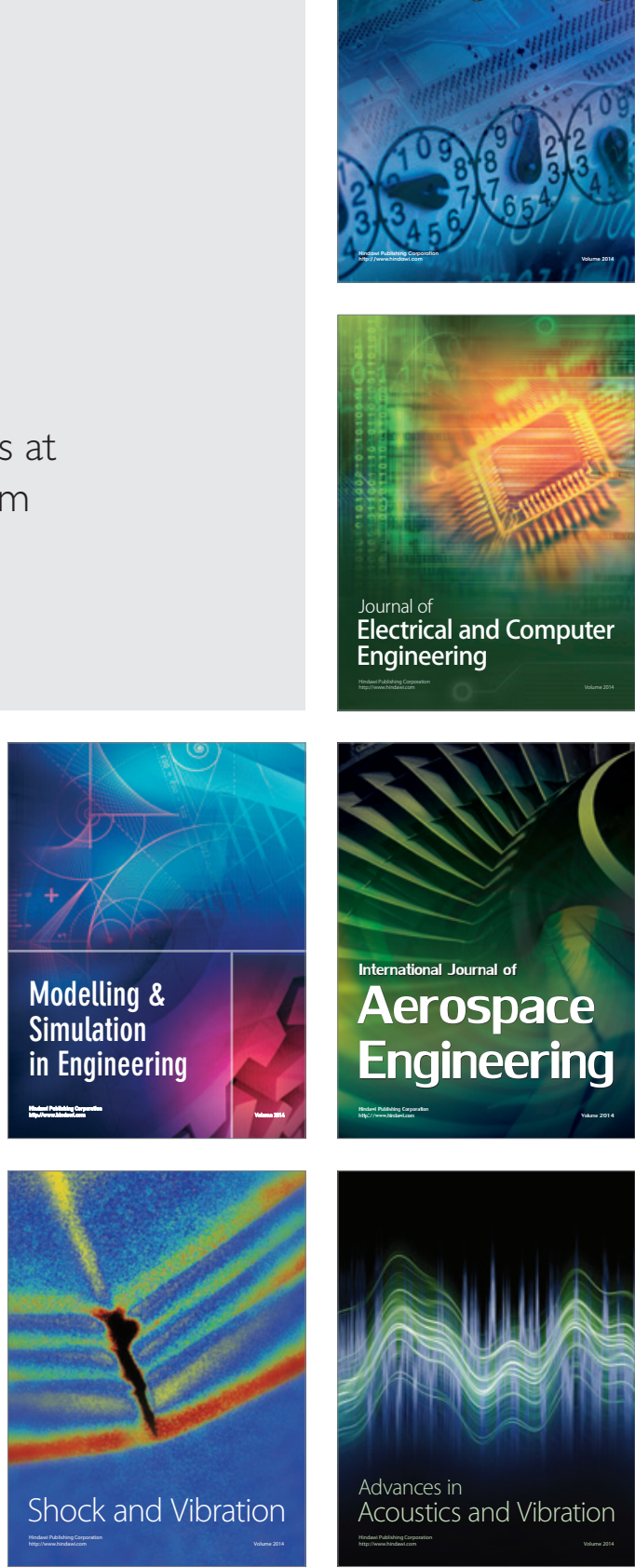